\title{
Coping with climate variability and non-climate stressors in the West African Oyster (Crassostrea tulipa) fishery in coastal Ghana
}

\author{
Sandra Akugpoka Atindana ${ }^{1}$ (D) Olajire Fagbola ${ }^{1} \cdot$ Emmanuel Ajani $^{1} \cdot$ Elliot Haruna Alhassan ${ }^{1} \cdot$ \\ Akwasi Ampofo-Yeboah ${ }^{1}$
}

Received: 25 April 2018 / Accepted: 16 January 2019/Published online: 20 February 2019

(C) The Author(s) 2019

\begin{abstract}
In Ghana, coastal shell fishery resources, particularly oysters, are envisaged to be heavily affected by changes in climate. The potential impacts will result from sea level rise, salinity changes and ocean acidification. The Whin Estuary, located at longitude $1^{0} 48 \mathrm{~W}$ and latitude $4^{0} 56 \mathrm{~N}$ of the Western Region of Ghana, is one of the few pristine coastal wetlands in the region with live oyster populations and a potential for fisheries sustenance. This paper examines adaptation strategies to changes in climate among female and male oyster collectors, constraints in the choice of adaptation strategies and land use stressors affecting the oyster fishery in Ghana. Participatory approaches such as participant observation, focus group discussions and key informant interviews were used to gather data on the indigenous knowledge of the fishery and climate variability. In the fishery, $60 \%$ of female oyster collectors adapt to prolonged dry periods through value chain addition practices and $45 \%$ are practicing other indigenous practices. The men adapt to changes in climate mainly by diversification. Kendall tau-b correlation analysis performed on adaptation practices showed no significant correlation $(\mathrm{r}=-0.667 ; p=0.174)$ between the adaptation practices ranked by male and female oyster collectors. There was a strong significant correlation $(p=0.05 ; \mathrm{r}=0.619)$ between constraints in the choice of adaptations among fishers. Presence of sewage outlets was the major threat (8), followed by uncontrolled mangrove cutting (7), sand winning (6) and the least of the threats were refuse dumps (4) and farming activities (3) following procedures of Battisti et al. (Biodiversity and Conservation 18 (11): 3053-3060, 2009) and Salafsky et al. (2003) ranking methods. In the context of climate variability, female oyster collectors may be more resilient in the oyster business than men; hence, they should be well resourced through capacity-building training programs. There is need for a redress of non-climate stressors by stakeholders through sensitization and strengthening of existing bye-laws. Proactive adaptive mechanisms blending both indigenous and scientific research-based strategies are essential for resilience in the phase of climate variability and sustainability of any management decision in fisheries.
\end{abstract}

Keywords Adaptation $\cdot$ Climate variability $\cdot$ Diversification $\cdot$ Oyster $\cdot$ Vulnerability

\section{Introduction}

The West African coastline is characterized by the presence of marginal estuaries of diverse morphologies and origins and are surrounded by high human population densities (Amadi 1990). Estuaries are classified based on various parameters such as the nature of sediment, salinity and mode of formation. On the basis of salinity, Ghana has three types of estuaries: (a) Positive estuary: when seawater enters it as a bottom current

Sandra Akugpoka Atindana

sandybrownatindana@gmail.com; saatindana@uds.edu.gh

1 University for Development Studies, Tamale, Ghana with the lighter freshwater leaving as a surface current into the sea, (b) negative estuary: occurs when the rate of evaporation exceeds the freshwater input and therefore results in hypersaline estuarine water which sinks and enters the sea as a bottom current; a typical example is the Whin Estuary, (c) neutral estuary: when there is a balance between evaporation and freshwater input, causing a more or less uniform salinity profile from the surface to the bottom; this type of estuary is rather rare (Yankson and Kendall 2001).

Estuaries in Ghana are the most valuable ecosystems since they are closely tied to salt marshes, mangrove swamps and tidal flats. These wetlands constitute significant features of Ghana's coastline, providing critical habitats for many fish and wildlife resources that support the country's economy. They are a vital source of recreation, conservation, nursery 
grounds for economically important marine birds, and important fisheries among which are oysters (McLusky 1989; Blaber 2008; Dahanayayaka and Aratne 2006; Woke and Wokoma 2000; Plavan et al. 2011).

The West African mangrove oyster (C. tulipa) is a tropical, euryhaline organism that thrives well at temperatures of 23$31{ }^{\circ} \mathrm{C}$. It can be cultured well in brackish mangrove swamps and sheltered aquatic areas of 2 to $5 \mathrm{~m}$ in depth, and matures in approximately 7-9 months (Ansa and Bashir 2007; Obodai 1999; Yankson 1990; Yankson and Obodai 1999; Kamara 1982). In these brackish systems, oysters most frequently attach themselves to the mangrove tree roots or, in the absence of such roots, to the rocky substrate of the wetland bottom. In Ghana, C. tulipa is most commonly found in not less than $90 \%$ of southern coastal estuaries and lagoons (Sultan et al. 2012).

Globally, bivalves play an important role in the national economy of many countries, be it in the form of a highly developed industry or as a source of cheap protein to many who need it. As reiterated by Quayle (1989), though shellfishes of most tropical and subtropical countries are exploited on a subsistence basis, especially the bivalves and crustaceans, they constitute a major source of much-needed protein for many rural communities. Studies on freshwater oyster and other bivalves in Ghana are well documented (Adjei-Boateng et al. 2010, 2016; Amoah et al. 2011; Adjei-Boateng and Wilson 2013; Ampofo-Yeboah and Owusu-Frimpong 2014). Despite the vulnerability of oysters to climate variability and change, there is no study on the adaptation strategies among oyster collectors in response to these changes in Ghana. This work aims at enhancing our understanding on how women and the few men who are involved in the fishery are adapting to climate variability and change and the need to redress nonclimate stressors that may further magnify impacts of changing climate on the fishery.

\section{Local effects of climate variability on oysters}

Changes in climate will affect the duration and frequency of tidal inundation and tidal current velocities in the sand flat, mud flat and channel bank habitats favored by oysters. This may lead to frequent storm surges, flooding and coastal erosion, expected to be exacerbated by other hazards such as cyclones, tsunamis and by anthropogenic activity (IPCC 2007, 2009).

The shells of oysters, made from calcium carbonate, are at particular risk from the lowering $\mathrm{pH}$ levels of ocean waters. The relative corrosiveness of seawater caused by lowering $\mathrm{pH}$ levels may cause adult and juvenile oysters to have trouble forming and maintaining their shells (Barton et al. 2012; La Peyre et al. 2009).

Availability of food for oysters from "calcifying" plankton species that require specific water chemistry for maintaining external calcium carbonate skeletons will be inhibited.

Increasing ocean temperature is likely to affect oysters by contributing to sea level rise (SLR) through the acceleration of glacier and polar ice cap melting and increased frequency and duration of harmful algal blooms. Increasing ocean temperatures in addition to high nutrient level and climate-related changes, according to the United States Environmental Protection Agency (USEPA), may also contribute to an increased frequency and intensity of harmful algal blooms (HABs). These overly abundant algal "blooms" can damage aquatic ecosystems by blocking sunlight and depleting the oxygen required by other organisms, including those that directly or indirectly contribute to clam and oyster food resources (USEPA 2013).

\section{Non-climate stressors affecting oyster abundance}

The unfavorable or destructive factors that tend to inhibit the growth and productivity of oyster communities are sedimentation, pollution, competition, disease and predation. The interaction of these factors acting simultaneously on a community determines its utilizable productivity. Pollutants that are of greatest impact on the health of estuaries include pathogens, toxic substances and nutrient pollution or eutrophication.

Eutrophication due to incessant human activities stimulates blooms of phytoplankton which can be harmful to oyster growth and survival. At a certain high concentration of several forms, such as Nitzschia closterium, Prorocentrum triangulatum, Euglena viridis, and Ohlorella sp., the rate of water transport of oysters is reduced and feeding ceases (Quayle 1989).

Reduced water depth due to accumulation of organic waste and siltation may interfere with the growth of phytoplankton that are food resources to the West African Oyster.

Rapid settling of suspended material induced by human activities or climate variability may be highly destructive to an oyster community. All coastal waters contain a certain amount of solids.

Prolonged siltation from erosion, raw sewage sludge and industrial waste causes gill irritation, buries oyster beds and reduces the smothering of oyster shells, thereby subsequently resulting in decreased reproduction, deterioration of estuarine water, loss of resilience, alteration of wetland habitats and, in extreme cases, results in mortality (Cinner et al. 2013; Soniate and Gauthier 1989).

The primary habitat of oysters are mangrove ecosystems where they thrive and are exploited by dependent communities. A report by Leith and Haward (2010) and NOAA (2010) shows that mangroves absorb higher levels of atmospheric carbon dioxide, approximately 5-8 times more than terrestrial ecosystems, thereby reducing global warming. 


\section{Materials and methods}

The study was undertaken in the Whin Estuary (Fig. 1) where female and male oyster collectors from three neighboring communities, New Amanfrul, Adakope and Apremdo, were purposively selected and interviewed. In 2010, New Amanfrul had a population of 2402 with few people engaged in fishing and subsistence farming. Fishermen in New Amanful are basically artisanal fisher folks (CRC/FON 2010). The months of August and September are regarded as good for farming as well as for fishing because it is the fish bumper season. Adakope is a mixed fishing and farming community that is bordered on the west by Takoradi Air force Military Base (CRC/FON 2010). The community, with a population of 1500 and 350 households, has farming employing about $75 \%$ of its indigenes.

The oyster fishery is predominantly made up of women with a few men. Out of a total of 80 oyster collectors, sixty comprising 30 women and 30 men were selected for the study. All men and women were interviewed and sampled proportional to their total number in the fishery.

Men and women involved in oyster harvest for a period of 20 years and above the age of 40 were purposively selected.
This procedure was adopted to interact with respondents who are previewed on historical changes in the climate and fishing activities (Bernard 2000).

The exponential non-discriminative snow-ball sampling technique was employed in selecting respondents from the three communities. This technique is useful in selection of research subjects where one subject directs the researcher to another and so on in a repeated manner which overcomes the challenges associated with sampling concealed populations (Vogt 1999). Key informants, such as the fishermen and women leaders, guided the identification of oyster collectors within the category of interest.

\section{Research approach}

The triangulation approach, using a variety of participatory tools including focus group discussions (FGDs), semistructured interviews, key informant interviews, expert interviews and observations, was used to collect data on indigenous knowledge, adaptations to changes in climate factors and existence of identified land-use stressors from March 2016 to March 2017. Additional information was collected at the district and regional scales through review of secondary

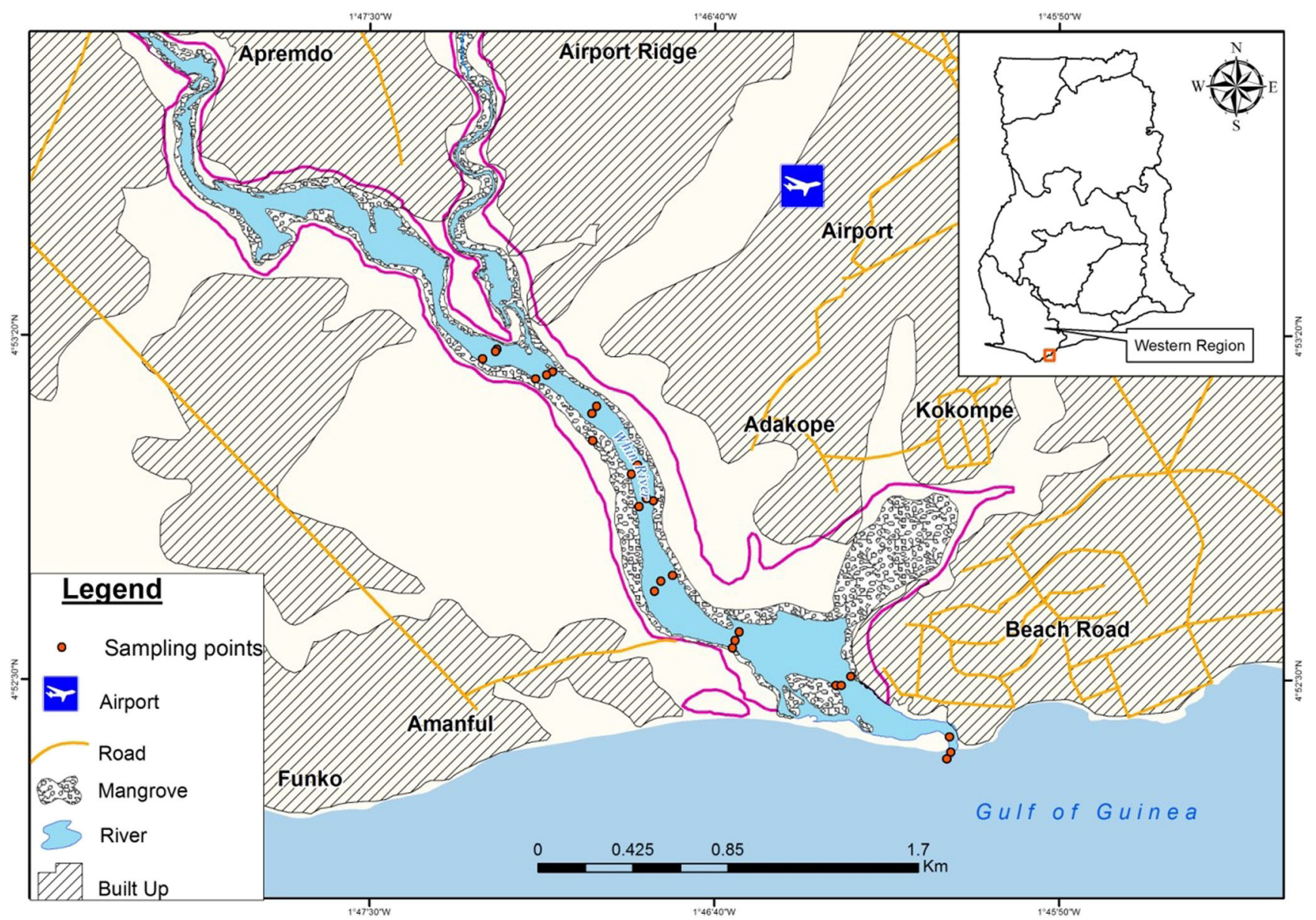

Fig. 1 Map showing the Whin Estuary and fishing communities, Western Region of Ghana 
information on physical and demographic features of the areas of study and how climate variability may affect oyster fisheries. Both indigenous and research-based adaptations were identified by the respondents and categorized based on three climate stimuli, rainfall-related, temperature-related and value chain addition (prolonged dry periods), and one non-climate driver, other indigenous strategies.

\section{Environmental assessment}

Identifying how many and which types of human-induced disturbances or threats are present and their regime is important when assessing the status of coastal wetlands of high conservation concern for efficient management (Hobbs and Huenneke 1992; Sutherland 2000; Salafsky et al. 2002, 2003).

In this regard, five environmental drivers of change, namely mangrove deforestation, farming activities, sand winning, refuse dumps and sewage outlets, were assessed to determine the severity of these threats on the wetland. The hierarchical classification of these threats was comprehensive (contains all possible items, at least at higher levels of the hierarchy), consistent (ensures that entries at a given level of the classification are of the same type), expandable (enables new items to be added to the classification if they are discovered) and exclusive (allows any given item to only be placed in one cell within the hierarchy) (Salafsky et al. 2008; Ter Braak 1986). Each assessment of the indicators was scored 1-4, 1 being the lesser impact and 4 the highest impact. Scope, severity and magnitude of the identified threats were assessed by following the categorical measurements proposed by Salafsky et al. (2003). More precisely, for "scope" we referred to the percentage ratio of the study area affected by a specific threat within the last 5 years (where $100 \%$ corresponds to total site area: 헻 ha) (Battisti et al. 2009). The scores were assigned as follows: 4: the threat is found throughout $(50 \%)$ the site area; 3: the threat is spread in 15-50\% of the study area; 2 : the threat is scattered (5-15\%); and 1: the threat is much localized $(<5 \%)$. Severity as the degree to which a threat has an impact on the viability/integrity of specific targets in the managed area within the last 5 years was ranked with the following scores; 4 if the direct threat induced serious damage to the targets, 3 if it induced a serious damage, 2 if it induced a moderate damage, and 1 , little or no damage. For each threat, we calculated its "magnitude" as a sum of scope and severity assigned to a specific threat, and the total values obtained were ranked.

This method is appropriate in order to evaluate those threats that are not empirically well known, have different metrics, are difficult to compare and thus the potential degree of uncertainty is very high (Hess and King 2002). Assessment of the area disturbed was carried out within a $1.2-\mathrm{km}$ radius starting from the hydric delineated zone of the wetland. This is because all land-use activities assessed were observed within the stated radius following a preliminary survey of the wetland.

\section{Data analyses}

Data collected from individual interviews were entered into a spreadsheet in Statistical Package of Social Sciences (SPSS, version 17). The qualitative data collected from both the key informant interviews and FGDs were analyzed through intensive content analysis to identify emerging themes and dominant narratives (Krippendorff 2004). Data on environmental stressors and adaptation strategies among fisher folks were analyzed in Microsoft Excel (2007) and results are represented on charts and tables.

Kendall's coefficient of concordance (W) was used to determine the degree of agreement among the rankings of the adaptations and constraints by the respondents using the rank scores (Legendre 2010). Kendall's coefficient of concordance (W) is expressed as:

$$
W=\frac{12\left[\sum \mathrm{r}^{2}-\left(\sum \mathrm{r}^{2}\right) / \mathrm{n}\right] / \mathrm{n},}{\left(\mathrm{nm}^{2}\left(\mathrm{n}^{2}-1\right)\right.}, \quad 0 \leq W \leq 1
$$

where $\mathrm{m}=$ number of raters, $\mathrm{n}=$ total number of objects being ranked and $r=$ coefficient of correlation between ranks.

\section{Results and discussions}

\section{Indigenous knowledge on climate indicators and adaptations strategies}

In Ghana, among coastal-dependent fishing communities, climate variability is perceived as affecting oyster harvest. The interviews and FGDs highlighted perceptions of evidences of climate variability such as increasing temperature, unpredictable rainfall patterns and shorter duration of rains (Fig. 3). All women $(100 \%)$ and men $(100 \%)$ identified increased temperature, decreased intensity and increased frequency of rainfall. A majority of fishers ( $85 \%$ ) reported that the timing of the wet and dry seasons has become less predictable. Among the fishers, $98 \%$ of them reported increase in temperature, while $79 \%$ identified frequent occurrences of floods.

Comparing temperature and rainfall data from the Takoradi Ghana Meteorological Agency (GMet), oyster collectors' observations of variations in climate factor clearly collaborated with historic trends of changes in climate in the region (Fig. 2). Meteorological data on the area is in line with projection of the Intergovernmental 

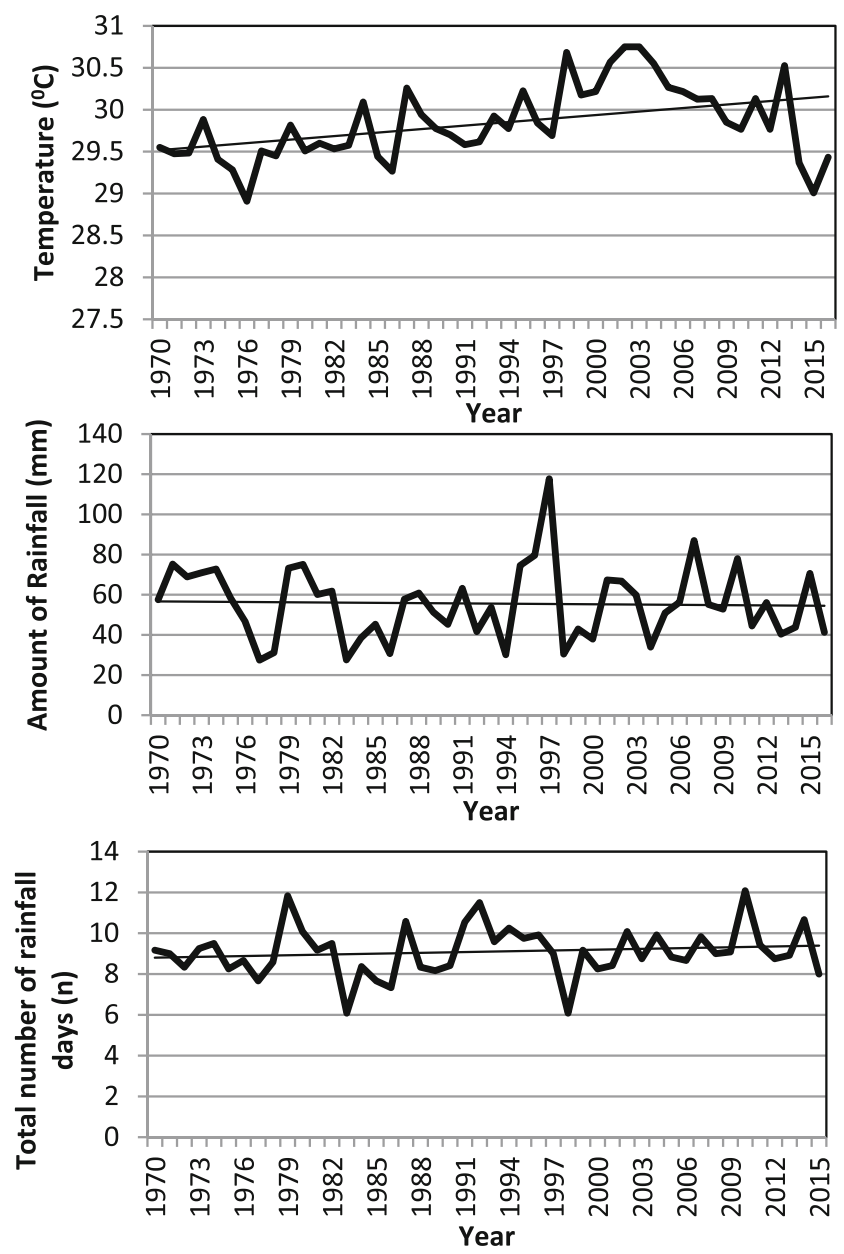

Fig. 2 Trend in climate indices from 1970 to 2015 in Western Ghana

Panel on Climate variability (IPCC 2009) on warming and erratic rainfall patterns in sub-regions of Africa.

In the industry, $87 \%$ of the fisher folks are women and $13 \%$ are men. Among the women who were interviewed, $90 \%$ were within the ages of 40-60 and 10\% were 61 years and above (Fig. 3). A majority of the men (30\%) were 60 years and above and a few of them (6\%) were between 40 and 60 years of age. A lot of works confirm that the Ghana oyster industry is dominated by women (Ampofo-Yeboah and Owusu-Frimpong
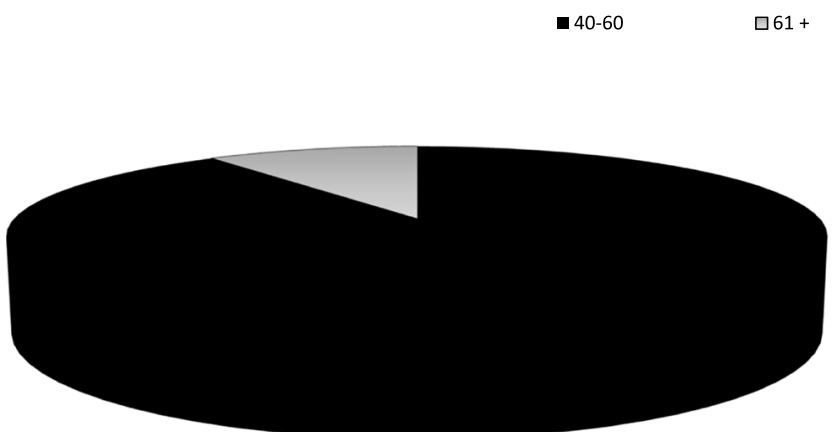

Fig. 3 Age distribution of respondents in the Whin Estuary, 2016
2014). In other parts of the world, particularly in Japan and the USA, the oyster sector comprises both elderly and young men and women (WHO 2010; Hess et al. 2012). Among African countries where oyster harvesting forms an integral part of livelihood needs, like Gambia, women predominate all processes in oyster harvesting, from shucking to sale.

This conforms to the composition of oyster collectors in Bayou, Le Batre, Louisiana and Southeast Asia where approximately $62 \%$ of oyster fisher folks are women (Hess et al, 2012).

The observed composition of gender in the Whin Estuary oyster industry is a peculiar phenomenon in most Sub-Saharan African countries like South Africa, Gambia, Nigeria and Ghana. This is probably due to the undeveloped nature of the oyster sector and the value chain not well appraised. Furthermore, the non-lucrative nature of the sector according to the men explains its predominance by women who engage in it mainly to harvest for home consumption.

The different age categories aided in understanding the vulnerable groups in the study communities and the coping strategies employed in combating the effects of climate variability. In this study, oyster collectors gave some reasons why the business is less patronized by male fisher folks, such as it being time-consuming and the laborious nature of the fishery coupled with low returns, availability of alternative highincome-earning jobs and lack of a ready market for oyster products. However, women partake in the business on a subsistence basis for household consumption and sale.

This study revealed that among the fisher folks, it is the aged who are committed to the business and harvest mainly for sale. If the value chain is well appraised and these old women were enabled, it will boost the oyster business and future sustainability of the fishery. For instance, one of the aged respondents stated that she is willing to be more active and committed to oyster harvest, but her age and unavailable financial support has rendered her incapable. The Ghana Livelihood Empowerment Against Poverty (LEAP) program, which offers support to extremely poor households, especially the aged, to tackle poverty by providing cash, is among existing incentive packages which will assist in the financial needs of fisher folks in the artisanal sector. Most of the men (90\%) had formal education, while a few of the women $(63.3 \%)$ were educated. However, most of the aged fishers had no formal education. Accessibility to financial support is partly influenced by one's level of education.

The men had easy access to loans which were channeled to other businesses than the women. This was reiterated by Akunga (2015) in a study in Mombasa and Malindi in Kenya, where the majority of fishers with some level of education were able to receive loans to support their fishing activities and were resilient to adverse effects of environmental and socio-economic disturbances. 
Table 1 Indigenous adaptation strategies among women fishers in the Whin Estuary, March 2016-March 2017

\begin{tabular}{|c|c|c|c|c|c|c|c|}
\hline Rainfall-related & $\begin{array}{l}\% \\
\text { Using }\end{array}$ & Temperature-related & $\begin{array}{l}\% \\
\text { Using }\end{array}$ & Value addition & $\begin{array}{l}\% \\
\text { Using }\end{array}$ & Other indigenous strategies & $\begin{array}{l}\% \\
\text { Using }\end{array}$ \\
\hline $\begin{array}{l}\text { Collection at edges of } \\
\text { estuary }\end{array}$ & 70 & Soaking of oysters & 84 & $\begin{array}{l}\text { Add value to oyster } \\
\text { meat }\end{array}$ & 87 & Allow siltation of estuary & 100 \\
\hline Staying off harvesting & 90 & Change in time of harvest & 78 & Sale of shells & 10 & $\begin{array}{l}\text { Alternative livelihood } \\
\text { ventures }\end{array}$ & 95 \\
\hline Use of improvised tools & 65 & $\begin{array}{l}\text { Preserve catch for lean } \\
\text { season }\end{array}$ & 69 & & & Observation of taboo day & 100 \\
\hline Wading over water & 10 & & & & & & \\
\hline
\end{tabular}

The indigenous adaptation strategies adopted by women and men are put into three climate stimuli, temperature, rainfall and value addition, and one non-climate driver, other indigenous strategies (Tables 1 and 2). During high temperatures, particularly in the months of January to April where oysters are more abundant, women in New Amanfrul, Adakope and Apremdo soak oysters immediately in pans of water for 6 days after collecting from the system. They then process the oysters by boiling to remove flesh and air-dry the meat as a way of coping with the climate-related stress of extreme heat that may lead to post mortem deterioration of the oysters. Women collectors are faced with the challenge of coping with floods during periods of heavy rains when the water level is high and less saline. They adapt mainly by collecting at the edges of the estuary and staying off harvesting for a period of 3 days for the water level to recede. Another observed adaptive measure was the use of improvised materials such as dropping of mangrove stems into the system as attachments for oyster spats to settle, subsequently resulting in easy collection. Value addition strategies among collectors were frying and drying oyster flesh for future use during lean seasons. Other indigenous strategies are observation of the closed season, alternative livelihoods (diversification) and allowing sedimentation of the system. Women diversify by abandoning the oyster business for petty trading, farming and sale of terrazzo. Conversely, some of the strategies such as siltation have adverse ecological implications on the resource, particularly sedentary species such as oysters.
For example, benthic filter-feeding organisms such as coral, oysters, shrimps and mussels are especially affected by silt-laden waters. Other harmful impacts of siltation are human health concerns, the loss of wetlands, coastline alterations, and changes in fish migratory patterns. Siltation in the estuary is largely due to natural and anthropogenic factors. The best approach is to manage the causes and the symptoms resulting from siltation. The ridge reef approach of managing upland activities will be a suitable solution to the causative factors. In managing symptoms, inlet training using jetties or by maintenance and controlled dredging of channels will be appropriate.

Heavy rains result in flood occurrences which reduces fishing effort due to decrease visibility, threat from loss of lives through drowning and high water depths rendering water inaccessible. Few experienced women (10\%) wade over water to collect oyster spats with a majority of women engaging the services of men. The challenge is women are unable to pay for services of men due to low income accrued from sales.

The fishers' capacity to cope and adapt to environmental variability depends on their knowledge, perceptions, institutions and individual and community-level characteristics. Furthermore, environmental variability affects associated human communities within a particular ecological, cultural, political and economic context (McCay 2002; Sievaren 2014). Fishers in the study communities, particularly women, have considerable indigenous knowledge regarding adaptations to extremes of climate variability.

Table 2 Indigenous adaptation strategies among fishermen in the Whin Estuary, March 2016-March 2017

\begin{tabular}{|c|c|c|c|c|c|c|c|}
\hline Rainfall changes & $\begin{array}{l}\% \\
\text { Using }\end{array}$ & Temperature changes & $\begin{array}{l}\% \\
\text { Using }\end{array}$ & Value addition & $\begin{array}{l}\% \\
\text { Using }\end{array}$ & Other strategies & $\begin{array}{l}\% \\
\text { Using }\end{array}$ \\
\hline $\begin{array}{l}\text { Collection at edges of } \\
\text { estuary }\end{array}$ & 70 & Soaking oysters & 0 & $\begin{array}{l}\text { Add value to } \\
\text { meat }\end{array}$ & 0 & $\begin{array}{l}\text { Allowing siltation of } \\
\text { estuary }\end{array}$ & 100 \\
\hline Staying off harvesting & 0 & Change in time of harvest & 10 & $\begin{array}{l}\text { Add value to } \\
\text { shells }\end{array}$ & 0 & $\begin{array}{l}\text { Alternative livelihood } \\
\text { ventures }\end{array}$ & 99 \\
\hline Use of improvised tools & 10 & $\begin{array}{l}\text { Preserve excess catch for lean } \\
\text { season }\end{array}$ & 5 & & & Observation of taboo day & 100 \\
\hline Wading over water & 80 & & & & & & \\
\hline
\end{tabular}


Conversely, except for information from GMet on weather forecasts, which is inaccessible to these areas, there are no functional institutions, policies or robust and reliable climate sensitization organizations. Such sources of support might otherwise equip fishermen and oyster collectors with information on predictions of future trends in climate variability through sensitization to enhance sustainable climate-resilient fisheries. According to Vásquez-León (1994), knowledge has been shown to be an important resource that allows smallscale fishers to adapt to variability in climate. In Gambia, a study by Woldff et al. (2016) in the Tanbi Wetland showed a low level of awareness of oyster farmers regarding the existence of adaptation strategies, despite the presence of and the developed nature of the oyster business in the country as compared to Ghana.

In view of the present state of the fisheries sector, Ghana has a potential to develop its artisanal oyster industry. Developing the oyster industry will augment catches from the marine artisanal sector, particularly the presently declining small pelagics, by meeting protein needs of these coastal communities and reducing food insecurity crises likely to arise in a decade.

The existence of institutions such as the Ministry of Fisheries and Aquaculture Development (MOFAD), Environmental Protection Agency, Friends of the Nations and Forestry Commission, in collaboration with Ghana's Sustainable Fisheries Management Project (SFMP), is a boost for Ghana's coastal oyster fisheries management and increase of its capacity. This initiative is developing women's capacity by training oyster collectors on water quality monitoring, mangrove restoration and aspects of biology and ecology of oysters geared towards managing stocks for nutritional and economic gains. Women are also trained on more improved methods of processing fish which. Among other capacities, such as the institution of a micro-finance insurance scheme under the auspices of USAID/Ghana SFMP for fishing communities in the country, are efforts at strengthening coping and adaptive capacities to environmental variability.

With the gradually developing shellfish sector, especially clams, the Ghana National Aquaculture Development Plan of the Fisheries Commission is planning research into the technical and economic feasibility of clam culture in the Volta Basin, and this is a prospect for future development of the oyster business. Furthermore, oyster is farmed on a commercial basis at two sites in Ghana, Tsokomey and Densu, under the Development Action Association. These prospects will support livelihood needs and provide economic gain to the country if sustainably managed.

Women in the New Amanfrul, Adakope and Apremdo oyster fisheries adopt varying coping strategies in response to climate variability compared to the men (Fig. 4i).

Perceived indigenous coping mechanisms to climate variability among women and men oyster harvesters in the Whin
Estuary revealed that $20 \%$ of the women are practicing rainfall-related indigenous strategies, $80 \%$ adopt temperature-related practices, $60 \%$ adopt changes in value addition methods and $45 \%$ are practicing other indigenous practices (Fig. 4i). The men have no strategies for coping with varying temperature $(0 \%)$ and prolonged dry spells $(0 \%)$ through value addition related (Fig. 3). From both respondent types, men were more adventurous than women and easily coped better with onsets of floods from erratic rainfall patterns. There is no significant correlation $(\mathrm{r}=-0.667 ; p=$ 0.174 ) between the adaptation practices ranked by oyster collectors. Rankings of women were negatively correlated $(\mathrm{r}=$ -0.667 ) with rankings of men (Table 3 ). Women adapted better to changes in temperature and rainfall, and added value to products to cope with varying climate, whereas men only coped by patronizing alternative job opportunities. Therefore, in the phase of resilience, women are better placed than men. Also, the research revealed higher vulnerability of men to adverse effects of changes in climate in the fishery than the women.

The women might have identified these coping strategies because oyster harvest, although on a subsistence basis, is their main source of livelihood in comparison with the men

(i)

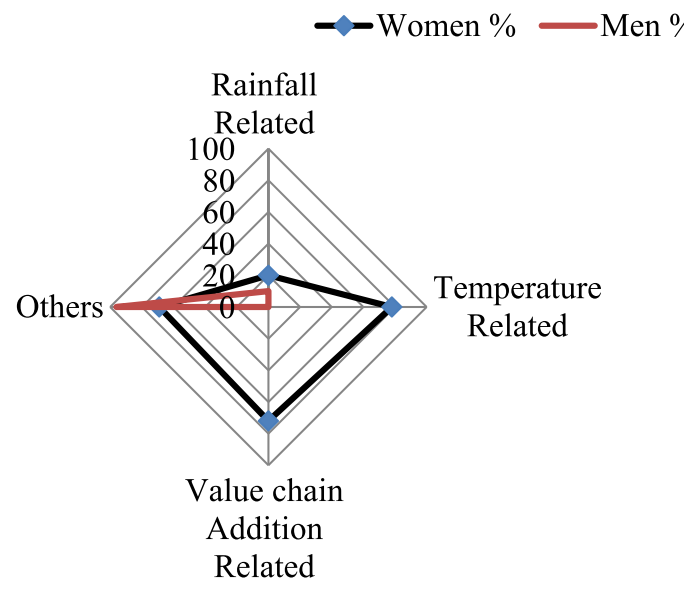

(ii)

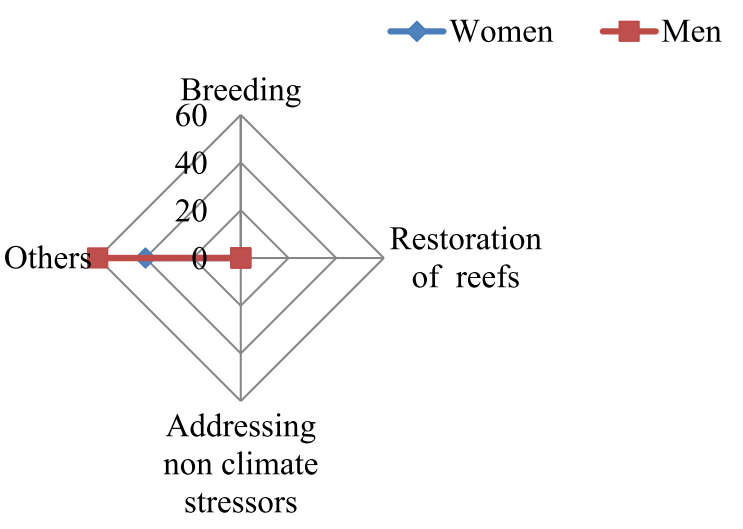

Fig. 4 Indigenous (i) and research-based (ii) adaptation practices identified among oyster collectors in the Whin Estuary, from March 2016 to March 2017 
Table 3 Kendall tau-b coefficients of correlation between adaptations strategies in the Whin Estuary, from March 2016 to March 2017

\begin{tabular}{lllrr}
\hline & & Women & \multicolumn{2}{c}{ Men } \\
\hline Kendall's tau-b & \multirow{2}{*}{ Women } & Correlation coefficient & $1.000 *$ & $-0.667 *$ \\
& & Significance (2-tailed) & - & 0.174 \\
& & 4 & 4 \\
& \multirow{2}{*}{ Men } & Correlation coefficient & $-0.667 *$ & $1.000 *$ \\
& & Significance (2-tailed) & 0.174 & - \\
& $N$ & 4 & 4 \\
\hline
\end{tabular}

*Correlation is not significant at the 0.05 level (2-tailed)

who are actively involved in the fin fisheries and sale of terrazzo which are high-income-earning jobs.

Individual interest, environmental variability and livelihood source are known to be driving forces to climate adaptation in fisheries and agricultural activities of rural and periurban areas in the sub-regions (McCay 2002; Sievaren 2014). The indigenous rainfall-coping strategies among respondents were wading over flooded waters, harvesting at the edges of the system and using improvised tools. In relation to temperature stressors, women change the time of harvest from late afternoon to early morning, and preserve excess catch for the lean season (rainy season) as this period (dry season) falls within the bumper season where water is more saline and the water level is low.

They also add value to oyster products by processing meat by adding spices, frying, smoking and packaging them for sale. This prolongs the shelf life of the meat while providing them income. The other indigenous methods are to diversify, allow the system to be silted and avoid harvesting oysters on Wednesdays (taboo day).

Some of these practices are recognized as not being directly linked with climate factors, but significantly enhance the replenishment of stocks, thereby reducing the wetland's vulnerability to effects of varying climate. The heavily silted system, although it allows fishers to cope with erratic rainfall patterns, is prone to floods and may lead to reduction in survival of oyster larvae and high mortality.

Findings similar to this study were obtained by Kovats and Tromp (2006) and Akunga (2015); the gender of fisher folks and level of adaptation to climate variability in America and Kenya shows that men represent the most vulnerable groups to climate stress. However, the authors associated their vulnerability to diseases, due to their long exposure to adverse weather conditions when fishing. The male oyster collectors in the Whin Estuary are vulnerable due to their low level of involvement in oyster harvesting, hence placing less priority to identifying ways of coping with climate stressors related to the oyster business. Therefore, interest plays a significant role in adopting coping mechanisms to adverse effects of climate variability in any sector.
Similar to several authors, the majority of fishers in some selected small-scale fishing communities in California and Taiwan effectively adopt temperature, wind and rainfall variability strategies for dealing with climate variability (Cheng et al. 2009; McCay et al. 2011; Musinguzi et al. 2015; Adger et al. 2003).

Some of these strategies are investing in boats with refrigerators, improving fish-processing techniques, diversification, changing fishing location, avoiding fishing, resorting to alternative livelihoods, increasing fishing effort and changing the time of harvest.

Heterogeneity in adaptation strategies at different scales suggests that regionally specific adaptation approaches will be most effective.

Though traditional approaches to fisheries management focus strongly on fishing, recent increase in climate impacts will require a new generation of management approaches. Among the four major categories of adaptations, the women respondents ranked temperature-related 1 st, value addition 2 nd, other indigenous practices 3rd and rainfall-related strategies, 4th. According to the respondents, rainfall practices were less sustainable compared with the other three indigenous methods for reasons such as the less resourceful nature of the community in terms of combating the adverse effects of climate variability stressors.

Respondents identified four research-based adaptations through the guide of the interviewer as breeding, addressing non-climate stressors, restoration of mangrove reefs and others research-based practices (Fig. 4ii). Among the fishers, diversification is highly practiced. The respondents have not heard of the possibility of breeding oysters to obtain lines that are resilient to adverse effects of varying climate, but may probably adapt better to efforts at addressing land-use stressors if they are sensitized and resourced through institutional support.

Recent scientific concerns are to conduct experimental trials to obtain breeds of oyster that have fast growth rates and use more energy in shell formation while maintaining $\mathrm{pH}$, a phenomenon called the "Goldlilocks".

These lines would absorb excess carbon dioxide in forming shells that otherwise could cause ocean acidification. Detrimental effects of accelerated SLR due to variability in climate have serious repercussions on oyster abundance. Restoration of oyster reef habitats remains one of the most effective remedies to the climate menace in oyster fisheries (Roudriquez et al. 2014).

Though it is evident, at local, national and global scales, that climate variability is and will have devastating effects on shell-forming organisms, the level of preparedness in relation to adaptations, resiliencies and hazards to climate variability is an indispensable necessity among fish-dependent coastal communities, and climate and research scholars (IPCC 2009; Barton et al. 2012; USEPA 2013). Some of the impacts will 
Table 4 Constraints in the choice of indigenous adaptation strategies among oyster collectors, 2016-2017

\begin{tabular}{|c|c|c|c|c|c|}
\hline \multirow[t]{2}{*}{ Constraints } & \multicolumn{2}{|c|}{ Women } & \multicolumn{2}{|c|}{ Men } & \multirow[b]{2}{*}{ Overall rank } \\
\hline & $N$ & Rank & $N$ & Rank & \\
\hline Frequent flood occurrences & 23 & 7 th & 18 & 7 th & 6th \\
\hline Laborious nature of business & 28 & $1 \mathrm{st}$ & 21 & 2nd & 1 st \\
\hline Lack of ready market & 23 & 2nd & 20 & 4th & 2nd \\
\hline Alternate livelihood sources & 27 & $3 \mathrm{rd}$ & 29 & $1 \mathrm{st}$ & $3 \mathrm{rd}$ \\
\hline Inaccessibility to weather information & 25 & 6th & 15 & 6 th & 7 th \\
\hline Lack of funds & 27 & 4th & 18 & 5 th & 4 th \\
\hline Lack of skills & 20 & 5 th & 17 & $3 \mathrm{rd}$ & 5 th \\
\hline
\end{tabular}

stem from ocean acidification, SLR, heavy rainfall, long periods of dry spells, heat waves, floods and low salinity.

It is imperative that sensitization of rural and peri-urban coastal fishing communities to research-based adaptation methods become key among stakeholders in complementing existing indigenous knowledge and practices.

Constraints in the choice of adopting coping strategies were the laborious nature of the business, lack of a ready market, lack of financial support and skills, alternative livelihood sources, lack of weather information and frequent floods (Table 4). There was a strong significant correlation ( $p=0.05$; $\mathrm{r}=0.619$ ) between constraints in the choice of adaptations among collectors (Table 5). Drudgery during harvest, lack of ready market, inadequate funds and skills and access to alternative livelihoods are the most pressing constraints in the choice of adaptation strategies among oyster collectors. The laborious nature of the business, lack of a ready market, alternative livelihood sources, inadequate financial support and skills, lack of weather information and frequent floods were ranked 1st, 2nd, 3rd, 4th, 5th and 6th, respectively (Table 4).

\section{Environmental factors influencing the fishery}

\section{Relationship between non-climatic stressors and oyster abundance}

Five land-use types, namely sewage outlets, indiscriminate mangrove cutting, sand winning, presence of refuse dumps and farming activities, were ranked with magnitudes of 8,7 , 6, 4 and 3, respectively (Fig. 5).

Among these non-climatic stressors in the area, the presence of sewage outlets was the major threat (8), followed by uncontrolled mangrove cutting (7), sand winning (6) and the least of the threats were refuse dumps (4) and farming activities (3). Two sewage outlets, one from Central Township of the region, spew domestic waste directly into the water. The other outlet is from a timber firm (Dupour Company) that preserves electricity poles by boiling with chemicals and disposes waste directly into water through their outlet.
Rapid settling of suspended material induced by human activities or climate variability may be highly destructive to an oyster community. Prolonged siltation from erosion, raw sewage sludge and domestic waste alters habitats, increases gill irritation, buries oyster beds and smothers oyster shells that subsequently results in decreased reproduction, growth rates and loss of resilience to climate variability effects. Untreated sewage containing water and nutrients gradually enriches systems with these substances. Nutrients accumulate and, in excess concentrations, results in eutrophication.

Eutrophication stimulates blooms of phytoplankton of several forms, such as Nitzschia closterium, Prorocentrum triangulatum and Euglena viridis, which are harmful to oyster growth (Quayle 1989). According to Leith and Haward (2010) and NOAA (2010), mangroves possess inherent abilities capable of absorbing about five and more times atmospheric carbon dioxide than terrestrial ecosystems, thereby playing a key role in curbing the menace of global warming. Indiscriminate mangrove cutting without replacement destroys the primary habitat of oysters, resulting in high mortality and contributing less to reducing global warming. The incessant destruction of the mangrove ecosystems in Ghana is because there is no legislation in Ghana which requires resource owners to replant, thin or prune mangrove seedlings.

Table 5 Kendall tau-b coefficients of correlation between constraints in the choice of adaptation strategies among oyster collectors in the Whin Estuary, 2016-2017

\begin{tabular}{lllrr}
\hline & & Women & Men \\
\hline Kendall's tau-b & \multirow{2}{*}{ Women } & Correlation Coefficient & $1.000 *$ & $0.619 *$ \\
& & Significance (2-tailed) & - & 0.051 \\
& & 7 & 7 \\
& \multirow{2}{*}{ Men } & Correlation Coefficient & $0.619 *$ & $1.000 *$ \\
& & Significance (2-tailed) & 0.051 & - \\
& $N$ & 7 & 7 \\
\hline
\end{tabular}

*Correlation is significant at the 0.05 level (2-tailed) 
Fig. 5 Land-use types and magnitude of threats in the Whin Estuary, 2016

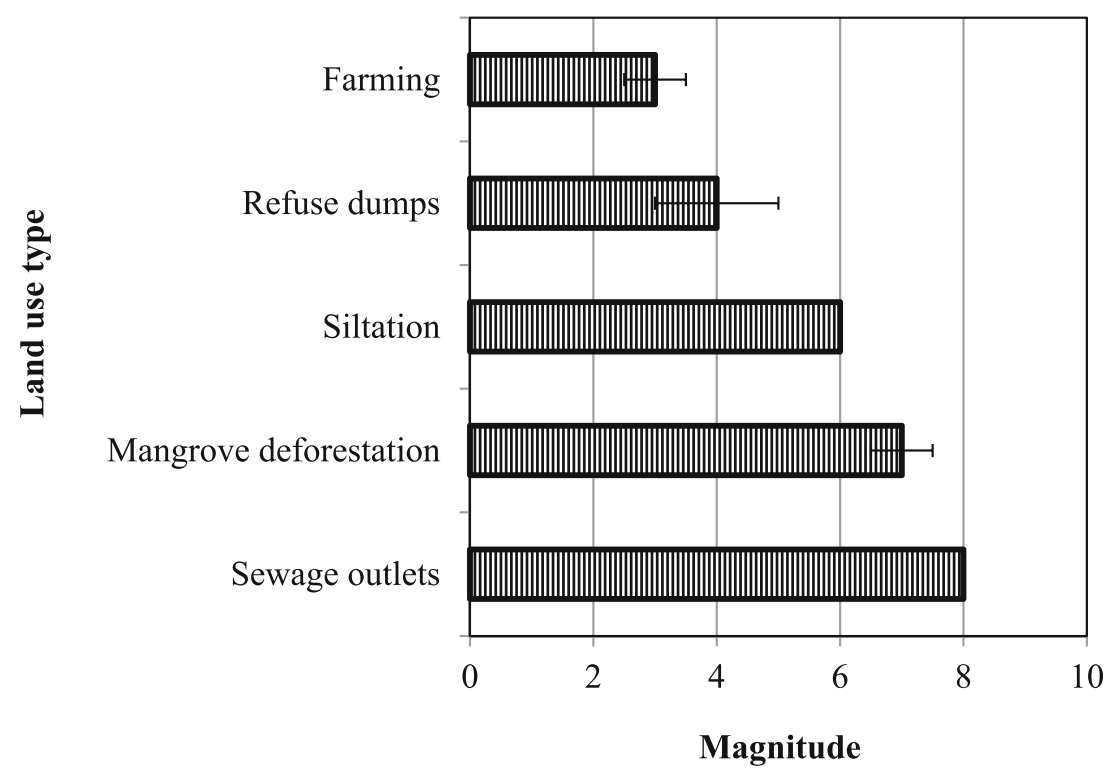

involved in initiatives by encouraging community participation in mangrove restoration programs and protection of existing natural barriers.

Robust measures need to be put in place by government and related agencies to address challenges posed by climate variability through policy formulation, decentralization of the meteorological services department, institutional strengthening through resources and capacity building. Building capacities to adapt to developing climate prediction technologies such as climate variability scenario models at institutional levels is necessary to strengthen disaster early warning systems by the Meteorological Department. In our next paper under review, we have developed a model for predicting the effects of climate change and variability on mollusk production in Ghana and its implications on oyster growth. This model is a baseline study for future predictions, but, like many other models, will require caution during its use and a frequent revision and update.

For sustainable oyster fisheries, government should institute policies on treatment of sewage before discharge into water, sensitize the populace on sustainable ways of cutting mangroves and creation of a buffer zone along the wetland.

Rehabilitation of mangrove ecosystems increases biodiversity and provides a sustainable livelihood for local inhabitants. In this regard, given the current rate of mangrove depletion in the area, it is recommended that stakeholders such as FON and MOFAD introduce the south eastern Asian palm Nypa fruticans to low-saline areas along estuaries, as successfully being practiced in Nigeria. Climate variability has food security implications, particularly renewable natural resources such as fisheries. It is important that prudent strategies be adapted to conserve these resources for the sustainability of fisheries resources. 
Open Access This article is distributed under the terms of the Creative Commons Attribution 4.0 International License (http:// creativecommons.org/licenses/by/4.0/), which permits unrestricted use, distribution, and reproduction in any medium, provided you give appropriate credit to the original author(s) and the source, provide a link to the Creative Commons license, and indicate if changes were made.

Publisher's note Springer Nature remains neutral with regard to jurisdictional claims in published maps and institutional affiliations.

\section{References}

Adger, W.N., S. Huq, K. Brown, D. Conway, and M. Hulme. 2003. Adaptation to climate change in the developing world. Progress in Development Studies 3 (3): 179-195.

Adjei-Boateng, D., and J.G. Wilson. 2013. Body condition and gametogenic cycle of Galatea paradoxa (Mollusca: Bivalvia) in the Volta River estuary, Ghana. Journal of Estuarine, Coastal and Shelf Science 132: 94-98. https://doi.org/10.1016/j.ecss.2011.06.018.

Adjei-Boateng, D., K.A. Obirikorang, and S. Amisah. 2010. Bioaccumulation of heavy metals in the tissue of the clam Galatea paradoxa and sediments from the Volta estuary. Ghana International Journal of Environmental Research 4 (3): 533-540.

Akunga, B.G. 2015. Influence of Climate change on Coastal Variability on coastal small-scale fishing communities in Kenya. A thesis submitted for the award of a doctor of philosophy degree, University of Kenyatta. 260pp.

Amadi, A.A.A. 1990. Comparative ecology of estuaries in Nigeria. Hydrobiologia 208: 27-38.

Amoah P., B. Keraita, P. Drechsel, R. Abaidoo, F. Konradsen, and M. Akple. 2011. Low cost options for health risk reduction where crops are irrigated with polluted water in West Africa. IWMI research Report No 141, Colombo, Sri Lanka.

Ampofo-Yeboah, A., and Owusu-Frimpong, M. 2014. The Fishery of the Freshwater Oyster Etheria Elliptica (Etheriidae) in Northern Ghana: Its Distribution and Economic Importance. Journal of Agriculture and Sustainability 5 (2): 211-220.

Ansa, E.J., and R.M. Bashir. 2007. Fishery and culture potentials of the mangrove oyster (Crasosstrea gasar) in Nigeria. Research Journal of Biological Sciences 2: 392-394 Frias-Esp.

Barton, A., B. Hales, G.G. Waldbusser, C. Langdon, and R.A. Feely. 2012. The Pacific oyster, Crassostrea gigas, shows negative correlation to naturally elevated carbon dioxide levels: Implications for near-term ocean acidification effects. Limnology and Oceanography 57 (3): 698-710.

Battisti, C., L. Luiselli, and C. Teofili. 2009. Quantifying threats in a Mediterranean wetland: Are there any changes in their evaluation during a training course? Biodiversity and Conservation 18 (11): 3053-3060.

Bernard, H.R. 2000. Social research methods: Qualitative and quantitative approaches. Thousand Oaks: Sage.

Blaber, S.J.M. 2008. Tropical estuarine fishes: Ecology, exploitation and conservation. Blackwell Science Limited. https://doi.org/10.1002/ 9780470694985.

Cheng, Y., Jeng-Di Lee, Li-ilian Liu, and Jin-ping Ueng. 2009. The adaptive strategies of oyster farmers to climate variation-typhoon in Tainan, Taiwan. FAO of UN.AGRIS. WWW.agris.fao.org/agrissearch. Accessed on Sept 5, 2017 at 8:00pm.

Cinner, J.E., N.A.J. Graham, C. Huchery, and M.A. Macneil. 2013. Global effects of local human population density and distance to markets on the condition of coral reef fisheries. Conservation Biology 27: 453. https://doi.org/10.1111/j.1523-1739.2012.01933x.
Coastal Resources Center / Friends of the Nation. 2010. Report on Characterization of coastal communities and shoreline environments in the Western region of Ghana. Integrated Coastal and Fisheries Governance Initiative for the West. Coastal Resources Center, University of Rhode Island, 425 pages.

Dahanayayaka, D.D.G.K., and M.J.W. Aratne. 2006. Diversity of Macrozoobenthic community in the Negombo estuary, Sri Lanka with special reference to environmental conditions. Sri Lanka Journal of Aquatic Sciences 11: 43-61.

Hess, G. R., and King T. J. 2002. Planning open spaces for wildlife. I. Selecting focal species using a Delphi survey approach. Landscape Urban Plan 58: 25-40.

Hess, L., Wang P. D'Odorico, J. P. Evans, D. J. Eldridge, M. F. McCabe, K. K. Caylor and King E.G. 2012. Dryland ecohydrology and climate change: critical issues and technical advances. Hydrology and Earth System Sciences, 16: 2585-2603. https://doi.org/10.5194/ hess-16-2585-2012.

Hobbs, R.J., and L.F. Huenneke. 1992. Disturbance, diversity, and invasion: Implications for conservation. Conservation Biology 6 (3): 324-337.

Intergovernmental Panel on Climate variability (IPCC). 2007. Climate variability 2007: Synthesis report. Fourth assessment report of the intergovernmental panel on climate variability. Cambridge: Cambridge University Press.

Intergovernmental Panel on Climate variability. IPCC. 2009. Climate variability: The physical science basis. Summary for policy. Cambridge: Cambridge University Press.

Kamara, A.B. 1982. Preliminary studies to culture mangrove oysters, Crassostrea tulipa, in Sierra Leone. Aquaculture 27: 285-294.

Kovats, D.K., and D.L.A. Tromp. 2006. Proposal and thesis writing, an introduction. Nairobi: Pauline's Publications Africa. Don Bosco Printing Press.

Krippendorff, K. 2004. Content analysis: An introduction to its methodology. Thousand Oaks: Sage.

La Peyre, M.K., B. Gossman, and J.F. La Peyre. 2009. Defining optimal freshwater flow for oyster production: Effects of freshet rate and magnitude of change and duration on eastern oysters and Perkinsus marinus infection. Estuaries and coasts. Estuarine Research Federation 32 (3): 522-534. 13pp. https://doi.org/10. 1007/s12237-009-9149-9.

Legendre, P. 2010. Species associations: The Kendall coefficient of concordance revisited. Journal of Agricultural, Biological, and Environmental Statistics 10: 226-245.

Leith, P.B., and M. Haward. 2010. Climate variability adaptation in the Australian edible oyster industry: An analysis of policy and practice. Hobart: University of Tasmania.

McCay, B.J. 2002. Emergence of institutions for the commons: Contexts, situations, and events. In The drama of the commons, ed. E. Ostrom, T. Dietz, N. Dolak, P.C. Stern, S. Stonich, and E.U. Weber, 361-402. Washington, DC: Nationa. Academy Press.

McCay, B.J., W. Weisman, and C.F. Creed. 2011. Coping with environmental change: Systemic responses and roles of property and community in three fisheries. In World fisheries: A social - ecological analyses, ed. R. Ommer, I. Perry, K. Cury, and P. Cochrane. Oxford: Wiley- Blackwell.

McLusky, D.S. 1989. The estuarine ecosystem. Vol. 2, 215. Glasgow: Blackie Academic and Professional Ltd.

Musinguzi, L., J. Efitre, K. Odongkara, R. Ogutu-Ohwayo, F. MuyodI, V. Natugonza, M. Olokotum, S. Namboowa, and S. Naigaga. 2015. Fishers' perceptions of climate change, impacts on their livelihoods and adaptation strategies in environmental change hotspots: A case of Lake Wamala, Uganda. Environment, Development and Sustainability 18: 1255-1273. https://doi.org/10.1007/s10668-0159690-6.

NOAA National Centers for Environmental Information, State of the Climate: Global Climate Report for Annual 2010, published online 
January 2011, retrieved on February 4, 2019 from https://www.ncdc. noaa.gov/sotc/global/201013.

Obodai, A.A. 1999. The present status and potential of the oyster industry in Ghana. Journal of Ghana Science Association 2 (2): 66-73.

Plavan, A.A., C. Passadore, and L. Gimenez. 2011. Fish assemblage in a temperature estuary on the Uruguay coast: Seasonal variation and environmental influence. Brazilian Journal of Oceanography 58 (4): 299-314.

Quayle, D.B. 1989. Tropical oysters: Culture and methods. Ottawa: International Development Research Centre TS17e. 80p.

Roudriquez, Antonio B., F. Fodrie, Justin T. Ridge, N. Lindquist, E. Theuerkauf, Sara E. Coleman, J.H. Grabowski, C. Brodeur Michelle, R.K. Gittman, Danielle A. Keller, and M.D. Kenworthy. 2014. Oyster reefs can outpace sea-level rise. Nature Climate Change 4: 493-497. https://doi.org/10.1038/nclimate2216.

Salafsky, N., R. Margoluis, K.H. Redford, and J.G. Robinson. 2002. Improving the practice of conservation: A conceptual framework and research agenda for conservation science. Conservation Biology 16 (6): 1469-1479.

Salafsky, N., D. Salzer, and J. Ervin. 2003. Conventions for defining, naming, measuring, combining, and mapping threats in conservation. An initial proposal for a standard system. http://www.fosonline. org/resource/conventions-for-threats. Accessed 5 Sep 2017.

Salafsky, N., D. Salzer, and A.J. Stattersfield. 2008. A standard lexicon for biodiversity conservation: Unified classifications of threats and actions. Conservation Biology 22 (4): 897-911.

Sievaren, L. 2014. How do small-scale fishers adapt to environmental variability? Lessons from Baja California, Sur, Mexico. Maritime Studies 13: 9. https://doi.org/10.1186/s40152-014-0009-2.

Soniat, T.M., and J.D. Gauthier. 1989. The prevalence and intensity of Perkinsus marinus eastern oysters and Perkinsus marinus infection. Estuaries and Coasts 32: 522-534.

Sultan, A.E., K. Yankson, and D.A. Wubah. 2012. The effect of salinity on particle filtration rates of the West African mangrove oyster. Journal for Young Investigators 24 (4): 55-59.
Sutherland, W.J. 2000. The conservation handbook, CAP - conservation action planning. Blackwell Science, Massachusetts TNC-WWF (The Nature Conservancy World Wide Fund). International Journal of Zoology for Nature), Massachusetts, Mass, USA. http:// conserveonline.Org/workspaces/cbdgateway/resources.

Ter Braak, C.J.F. 1986. Canonical correspondence analysis: A new eigenvector technique for multivariate direct gradient analysis. Ecology 67 (5): 1167-1179.

USEPA. 2013. Report on the 2013 U.S. Environmental Protection Agency (EPA) International Decontamination Research and Development Conference. Research Triangle Park, NC, November 05 - 07, 2013. U.S. Environmental Protection Agency, Washington, DC, EPA/600/R-14/210, 2014.

Vásquez-León, M. 1994. Avoidance strategies and governmental rigidity: The case of the small-scale shrimp fishery in two Mexican communities. Journal of Political Ecology 1: 67-81.

Vogt, W.P. 1999. Dictionary of statistics and methodology: A nontechnical guide for social sciences. London: Sage.

Woke, G.N., and A.I.P. Wokoma. 2000. Effect of organic waste pollution on the Macrozoobenthic organisms of the Elechi Creek, Port Harcout. African Journal of Applied Zoology and Environmental Biology 1 (3): 197-200.

World Health Organization (WHO). 2010. In Safe management of shellfish and harvest waters, ed. G. Rees, K. Pond, D. Kay, J. Bartram, and J. Santo. London: IWA.

Yankson, K. 1990. Preliminary studies on the rearing of West African mangrove oyster, Crassostrea tulipa, in the laboratory. Discovery and Innovation 2: 45-51.

Yankson, K., and M. Kendall. 2001. A student's guide to the Fauna of seashores in West Africa. Newcastle: Darwin Initiative.

Yankson, K., and E.A. Obodai. 1999. An update on the number, types and distribution of coastal lagoons in Ghana. Journal of Ghana Science Association 2: 26-31. 